Research paper

\title{
Differentiation and growth of a growing point until the stage of flower bud appearance in leading common buckwheat and Tartary buckwheat varieties in northern Japan
}

\author{
Shinya KASAJIMA*, Ikumi YOSHIMARU, and Hirotake ITOH \\ Faculty of Bioindustry, Tokyo University of Agriculture, Yasaka 196, Abashiri, Hokkaido 099-2493, Japan \\ * Corresponding author, e-mail: s3kasaji@nodai.ac.jp \\ Tel: +81-152-48-3823 \\ Other e-mail addresses: \\ Ikumi Yoshimaru, yoshimaru193@yahoo.co.jp, Hirotake Itoh, h-ito@nodai.ac.jp
}

DOI https://doi.org/10.3986/fag0009

Received: April 11, 2019; accepted: June 8, 2019

Keywords: common buckwheat, developmental stage, growing point, Hokkaido, Tartary buckwheat

\begin{abstract}
Studies regarding the developmental stage of common buckwheat (Fagopyrum esculentum Moench) have not been adequately performed despite its importance in studying the yield-determining process. In addition, the difference between common buckwheat and Tartary buckwheat (F. tataricum (L.) Gaertn.) is still unclear. In the present study, the differentiation and growth of the growing point until the stage of flower bud appearance were evaluated in the common buckwheat variety 'Kitawasesoba' and the Tartary buckwheat variety 'Manten-Kirari', which are the leading buckwheat varieties in Hokkaido, Japan. With some exceptions, the developmental stages of 'Kitawasesoba' and 'Manten-Kirari' can be distinguished. Thus, leaf primordia, axillary flower bud, and terminal flower bud differentiations and growths were observed. Both the common and Tartary buckwheat varieties did not exhibit large differences in the morphology of the growing point. However, the two varieties showed differences in the rates of differentiation and growth.
\end{abstract}




\section{INTRODUCTION}

Buckwheat (family Polygonaceae) is a pseudocereal crop with beneficial effects on human health (Ikeda 2002; Ikeda et al. 2012). Common buckwheat (Fagopyrum esculentum Moench) and Tartary buckwheat (F. tataricum (L.) Gaertn.) are the well-known members of the Fagopyrum genus. Common buckwheat bears beautiful and abundant flowers. However, due to self-incompatibility, its seed set is generally low, implying poor seed yield (Woo et al. 2016). Currently, the seed yield of common buckwheat in Japan is less than $1,000 \mathrm{~kg} \mathrm{ha}^{-1}$. The yield of Tartary buckwheat is generally higher than that of common buckwheat as Tartary buckwheat is an autogamous plant with high fertilization efficiency. However, the seed yield of Tartary buckwheat is still much lower than that of major grain crops such as wheat and rice.

In buckwheat, the seed yield per unit area is determined by the yield component, i.e., the number of bloomed florets per unit area, fertilization rate, the percentage of ripened seeds, and seed weight (Ujihara and Matano 1975; Kasajima et al. 2011). The number of bloomed florets per unit area includes the number of flower clusters per unit area and the number of bloomed florets per flower cluster. In buckwheat, the number of flower clusters and the number of bloomed florets are considered to be important factors governing seed yield. In wheat, the grain number per spike is closely related to the formation and development of spikelets and florets (Miralles and Slafer 1999; Toyota et al. 2001). Similarly, in buckwheat, flower bud differentiation is thought to be related to the number of seeds based on the number of flower clusters and florets. Few studies have reported observations regarding flower bud differentiation in common buckwheat. Hagiwara et al. (1998) reported the criteria for determining the developmental stage of the growing point in common buckwheat. Although common buckwheat is important for examining the yield-determining process, detailed studies assessing its developmental stage have not yet been conducted. In addition, the difference between common buckwheat and Tartary buckwheat is still unknown.

In Japan, the largest buckwheat-producing region is Hokkaido, which lies in the northern part of the country. Common buckwheat production in Hokkaido accounts for approximately $40 \%$ of its total production in Japan (Morishita and Suzuki 2012). For approximately past three decades, the common buckwheat variety 'Kitawasesoba' has been the main cultivated variety of buckwheat in Hokkaido. In addition, there has been an increased cultivation of Tartary buckwheat in Hokkaido. Suzuki et al. (2014) developed a new Tartary buckwheat variety, 'Manten-Kirari', the flour of which contains only trace amounts of rutinosidase and thus, lacks the bitter taste associated with buckwheat. The cultivation and use of 'Manten-Kirari' have rapidly grown in Hokkaido. Thus, 'Kitawasesoba' and 'Manten-Kirari' are the leading varieties of common and Tartary buckwheat, respectively, grown in Hokkaido. There is a lack of basic research from the viewpoint of developmental stages to realize high-yield capabilities of these varieties.

The present study aimed to describe the differentiation and growth of a growing point until the stage of flower bud appearance in the leading common and Tartary buckwheat varieties 'Kitawasesoba' and 'Manten-Kirari', respectively, in Hokkaido, northern Japan.

\section{MATERIALS AND METHODS}

'Kitawasesoba' and 'Manten-Kirari' varieties developed by the NARO Hokkaido Agricultural Research Center were used in the present study (Inuyama et al. 1994; Suzuki et al. 2014). Under experimental conditions, the seeds of these varieties were sown in plastic planters measuring $56.5 \times 17 \times 16 \mathrm{~cm}$ (length $\times$ width $\times$ height) that were filled with commercial garden soil containing $0.374 \mathrm{~g} \mathrm{~kg}^{-1} \mathrm{~N}, 1.485 \mathrm{~g} \mathrm{~kg}^{-1} \mathrm{P}_{2} \mathrm{O}_{5}$, and $0.242 \mathrm{~g}$ $\mathrm{kg}^{-1} \mathrm{~K}_{2} \mathrm{O}$. The experiment was conducted in a greenhouse with all sides open at the Faculty of Bioindustry, the Tokyo University of Agriculture in Hokkaido, Japan, in the summer of 2018. Ten planters of each variety were placed in the greenhouse, and approximately 120 plants of each variety were grown in a completely randomized design with two replications. A depression measuring approximately $2-\mathrm{cm}$ in depth was made in the middle of the soil in the planters, and 24 seeds, equivalent to 250 seeds/ square meter, were sown per planter on June 10, 2018. Plants were irrigated daily with tap water, and no fertilizer was applied.

Plants were sampled twice a week from the beginning of July to middle of August to observe the development of the growing point on the shoot. The growing points of three plant samples per plot were immediately dissected under a stereoscopic microscope to estimate the developmental stage of the growing points. The side views of the growing points were observed using a tablet in conjunction with the microscope. The vertical length of the grow- 
ing point was recorded using the software in the tablet. The definitions of the developmental stages of both the varieties generally followed those reported by Hagiwara et al. (1998).

\section{RESULTS AND DISCUSSION}

In the present study, the developmental stages of the common buckwheat variety 'Kitawasesoba' and the Tartary buckwheat variety 'Manten-Kirari' were distinguished, with some exceptions, according to the criteria reported by in a study by Hagiwara et al. (1998) that used common buckwheat. Three primary developmental stages have been reported: (A) leaf primordia differentiation and growth period, (B) axillary flower bud differentiation and growth period, and (C) terminal flower bud differentiation and growth period. In the present study, the developmental stages of both common buckwheat and Tartary buckwheat were almost consistent with the aforementioned stages. The typical and easily-discernible pictures of each developmental stage are shown in Figs. 1-3.

Fig. 1 depicts leaf primordia differentiation and growth period in 'Manten-Kirari'. We did not observe the growing point with leaf primordia in 'Kitawasesoba'. The growing point in Fig. 1 A0 showed the formation of only leaf primordia. An axillary bud was observed on the growing point along with the growth of leaf primordial (Fig. 2 A1). In higher plants, vegetative growth can be divided into juvenile and adult phases (Bäurle and Dean 2006; Yoshikawa et al. 2013). In the present study, the difference between the juvenile and adult phases was difficult to discern, although the morphological characteristics of growing points were observed in the vegetative growth period.

Fig. 2 depicts axillary differentiation and the growth period in 'Kitawasesoba' and 'Manten-Kirari'. In Fig. 2 B0,
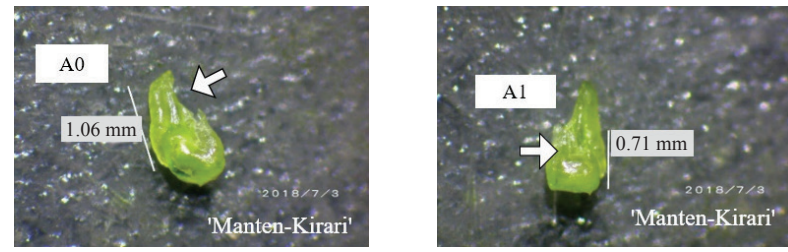

Fig. 1. Leaf primordia differentiation and growth period in 'Manten-Kirari'.

(AO) Growing point initiates only leaf primordia. The arrow shows the leaf primordia. (A1) Leaf primordia and axillary buds

differentiate on the growing point. The arrow shows the axillary buds.
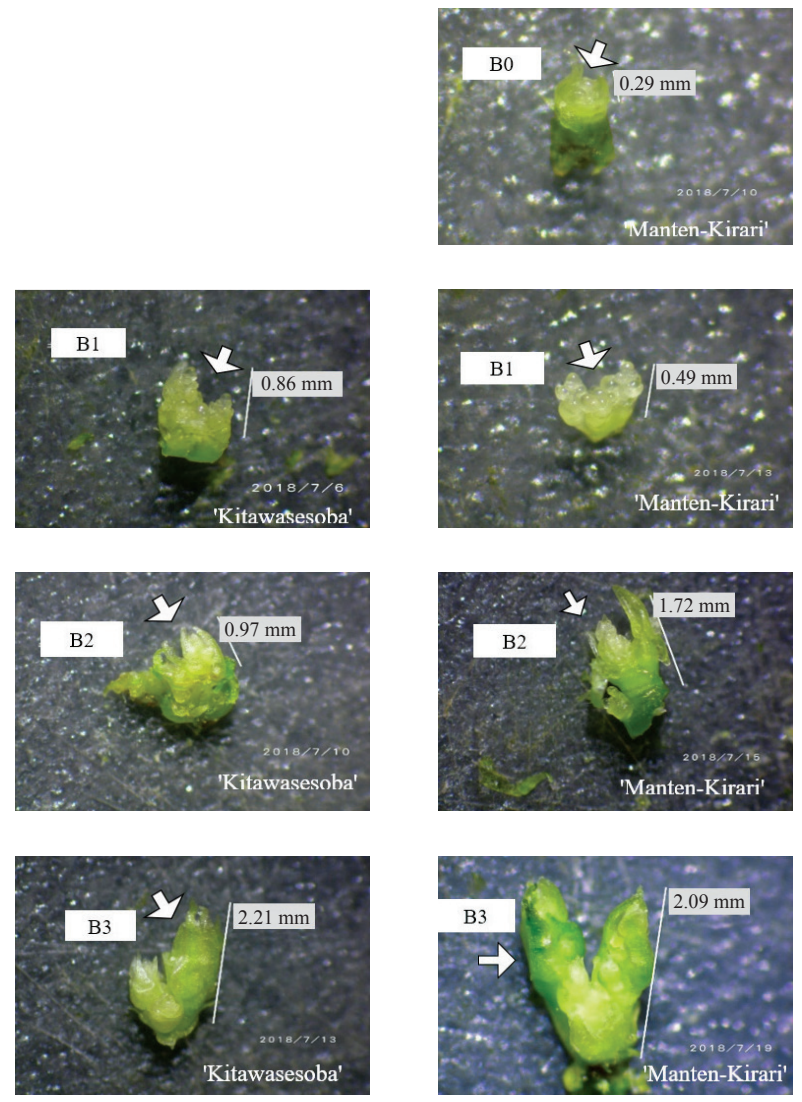

Fig. 2. Axillary bud differentiation and growth period in 'Kitawasesoba' (left) and 'Manten-Kirari' (right).

(BO) Apical growing point and axillary bud primordia grew into a dome-shaped structure. The arrow shows the dome differentiated on the growing point. (B1) Numerous small projections formed on the surface of the dome differentiated at $B 0$. The arrow shows the small projections. (B2) A flower bud grows and is covered with bract, which is indicated by the arrow. (B3) Flower bud grows and floret clusters covered with bract are visible. The arrow shows a floret cluster.

the apical growing point and axillary bud primordia grew into a dome-shaped structure. However, the differentiated dome on the growing point could not be observed in 'Kitawasesoba'. As seen in Fig. 2 B1, numerous small projections were formed on the surface of the dome differentiated in Fig. 2 B0. A flower bud grew and was covered with a bract (Fig. 2 B2). The flower bud grew, and floret clusters were found to be covered with a bract (Fig. 2 B3). In the growing point in B3, leaf primordia and flower buds simultaneously differentiated (Hagiwara et al. 1998). In general, buckwheat exhibits an indeterminate growth pattern that is based on indeterminate inflorescence. 
Conversely, simultaneous ripening is a characteristic of determinate varieties of common buckwheat (Martinenco and Fesenko 1989). Therefore, the differentiation and growth of the growing point may vary between determinate and indeterminate common buckwheat varieties. Further studies that compare the growing point in determinate and indeterminate common buckwheat varieties are required to elucidate the effect of the overlapping period of vegetative and reproductive primordia on the agronomic characteristics of buckwheat.

Fig. 3 depicts terminal flower bud differentiation and growth period in 'Kitawasesoba' and 'Manten-Kirari'. As seen in Fig. 3 CO, the differentiation of the axillary flower
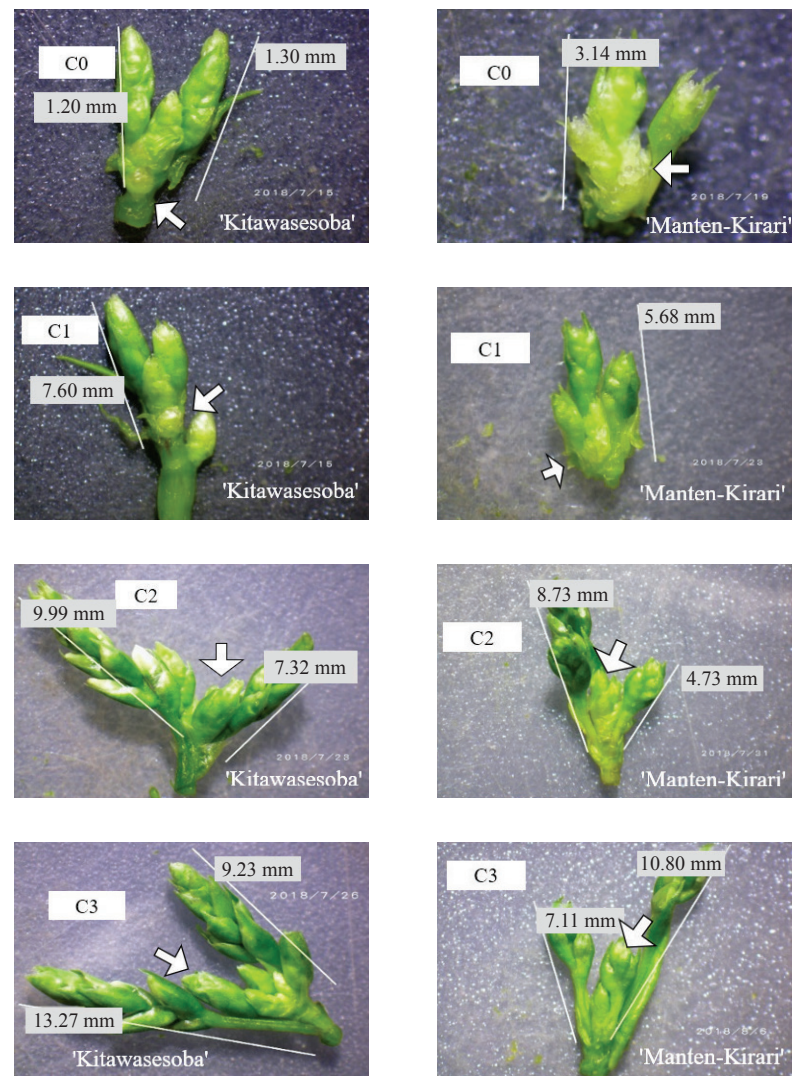

Fig. 3. Terminal flower bud differentiation and growth period in 'Kitawasesoba' (left) and 'Manten-Kirari' (right).

(CO) Differentiation of axillary flower bud ceases, and the apical growing point changes again into the dome-shaped structure. The arrow shows the dome differentiated on the apical growing point. (C1) The dome-shaped growing point is covered with small projections (indicated by the arrow). (C2) Terminal flower bud growth and floret clusters formed from the small projections can be seen. The arrow shows visible floret clusters. (C3) Floret clusters grow and are covered with bract (indicated by the arrow). bud ceased, and the apical growing point changed again into a dome-shaped structure. A dome-shaped growing point was found to be covered with small projections (Fig. 3 C1). Terminal flower bud growth and floret clusters formed from the small projections were visible (Fig. 3 C2). The floret clusters grew and were covered with bract (Fig. 3 C3). The results depicted in Figs. 1-3 show no large differences in the developmental morphology of the growing points of common buckwheat and Tartary buckwheat.

Fig. 4 depicts the mean vertical length of the growing points in 'Kitawasesoba' and 'Manten-Kirari'. The expansion of the size of the growing point in both 'Kitawas-

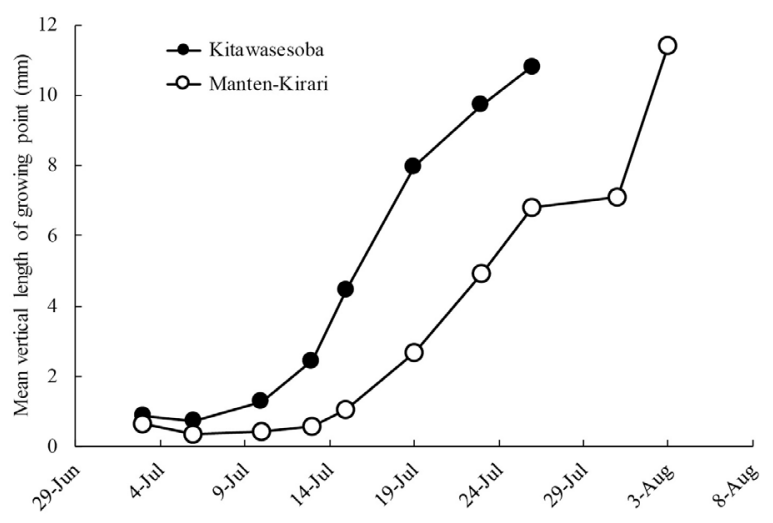

Fig. 4. Mean vertical length of growing point in 'Kitawasesoba' and 'Manten-Kirari'.

esoba' and 'Manten-Kirari' showed an S-shaped curve. However, the expansion was delayed in 'Manten-Kirari' compared with that in 'Kitawasesoba'. In addition, the onset of the expansion of the growing point was more rapid in 'Kitawasesoba' compared with that in 'Manten-Kirari', which may lead to a difficulty in identifying the developmental stage of the vegetative growth period in 'Kitawasesoba'. Thus, the sampling frequency should be increased to observe the growing point during the vegetative growth period of common buckwheat.

In conclusion, there were no large differences in the morphology of the growing points of common buckwheat and Tartary buckwheat. However, differences were observed in the rates of differentiation and growth in the two varieties. In Japan, buckwheat is very sensitive to environmental stresses such as flooding stress during floral 
transition in the developmental stage. In further studies, we will conduct a more accurate evaluation of the growing point during floral transition and of its association with abiotic environments.

\section{ACKNOWLEDGEMENTS}

We thank Dr. N. Inoue and Dr. M. Hagiwara of the Shinshu University for their valuable advice and Jinmon Co. Ltd. for providing 'Manten-Kirari' seeds.

\section{REFERENCES}

Bäurle, I. and C. Dean, 2006. The timing of developmental transitions in plants. CELL 125: 655-664. DOI: https://doi. org/10.1016/j.cell.2006.05.005

Hagiwara, M., N. Inoue and T. Matano, 1998. Variability in the length of flower bud differentiation period of common buckwheat. FAGOPYRUM 15: 55-64.

Ikeda K, 2002. Buckwheat composition, chemistry, and processing. ADV FOOD NUTR RES 44: 395-434. DOI: https:// doi.org/10.1016/S1043-4526(02)44008-9

Ikeda, K., S. Ikeda, I. Kreft and R. Lin, 2012. Utilization of Tartary buckwheat. FAGOPYRUM 29: 27-30.

Inuyama, S., Y. Honda, S. Furuyama, M. Kimura and H. Kasano, 1994. The breeding and characteristics of a buckwheat cultivar, "Kitawasesoba." RES BULL HOKKAIDO NATL AGRIC EXP STN 159: 1-10. (In Japanese with English Summary)

Kasajima, S. and H. Itoh, 2011. Effect of shading during different growth phases on yield parameters of common buckwheat cv. Kitawasesoba in the northern region of Japan. FAGOPYRUM 28: 43-46.

Martinenko, G. E. and N. V. Fesenko, 1989. Selection of determinant buckwheat varieties. INPROC 4TH INT SYMP ON BUCKWHEAT OREL, USSR 342-243.

Morishita, T. and T. Suzuki, 2012. Buckwheat varieties and trend of cultivation in Hokkaido, Japan. RESEARCH JOURNAL OF FOOD AND AGRICULTURE 35: 9-12 (In Japanese).

Miralles, D. J. and G. A. Slafer, 1999. Wheat development. In Satorre E. H. and G. A. Slafer (Eds.), Wheat: ecology and physiology of yield determination. pp. 13-43, Food Products Press, New York.

Suzuki, T., T. Morishita, Y. Mukasa, S. Takigawa, S. Yokota, K. Ishiguro and T. Noda, 2014. Breeding of 'Manten-Kirari', a non-bitter and trace-rutinosidase variety of Tartary buckwheat (Fagopyrum tataricum Gaertn.). BREED SCI 64: 344350. DOI: https://doi.org/10.1270/jsbbs.64.344

Toyota, M., I. Tsutsui, A. Kusutani and K. Asanuma, 2001. Initiation and development of spikelets and florets in wheat as influenced by shading and nitrogen supply at the spikelet phase. PLANT PROD SCI 4: 283-290. DOI: https://doi. org/10.1626/pps.4.283

Ujihara, A. and T. Matano, 1975. Characteristics of flowering, fertilization and fructification - approaches to yielding process. J AGRI SCI 30: 406-408. (In Japanese)

Woo, S. H., S. K. Roy, S. J. Kwon, S. W. Cho, K. Sarker, M. S. Lee, K. Y. Chung and H. H. Kim, 2016. Concepts, prospects, and potentiality in buckwheat (Fagopyrum esculentum Moench): a research perspective. In: Meiliang, Z., I. Kreft, S. H. Woo, N. Chrungoo and G. Wieslander (Eds.), Molecular Breeding and Nutritional Aspects of Buckwheat, pp. 21-49, Academic Press, London.

Yoshikawa, T., S. Ozawa, N. Sentoku, J. Itoh, Y. Nagato S. Yokoi, 2013. Change of shoot architecture during juvenile-to-adult phase transition in soybean. PLANTA 238: 229-237. DOI: https://doi.org/10.1007/s00425-013-1895-z

\section{IZVLEČEK}

Faze razvoja rastlin navadne ajde (Fagopyrum esculentum Moench) še niso bile ustrezno raziskane; so pa pomembne za formiranje pridelka ajde. Poleg tega še niso jasne morebitne razlike pri razvoju navadne in tatarske ajde (F. tataricum (L.) Gaertn.). V tej študiji sta bili proučeni rast in razvoj točke rasti vse do faze nastanka cvetnih brstov, pri navadni ajdi, sorta 'Kitawasesoba' in tatarski ajdi, sorta 'Manten-Kirari'. Ugotovljene so razlike v fazah razvoja med obema kultivarjema. Obe proučevani sorti sta vodilni pri pridelovanju ajde na otoku Hokkaido, Japonska. Raziskani so listni primordiji, stranski in glavni cvetni brsti in apikalna točka rasti. Glede morfologije točke rasti ni bistvenih razlik med kultivarjema, se pa rastline obeh raziskanih kultivarjev razlikujejo v stopnjah diferenciacije in rasti. 